\title{
Future $\mathrm{CO}_{2}$-induced seawater acidification mediates the physiological performance of a green alga Ulva linza in different photoperiods
}

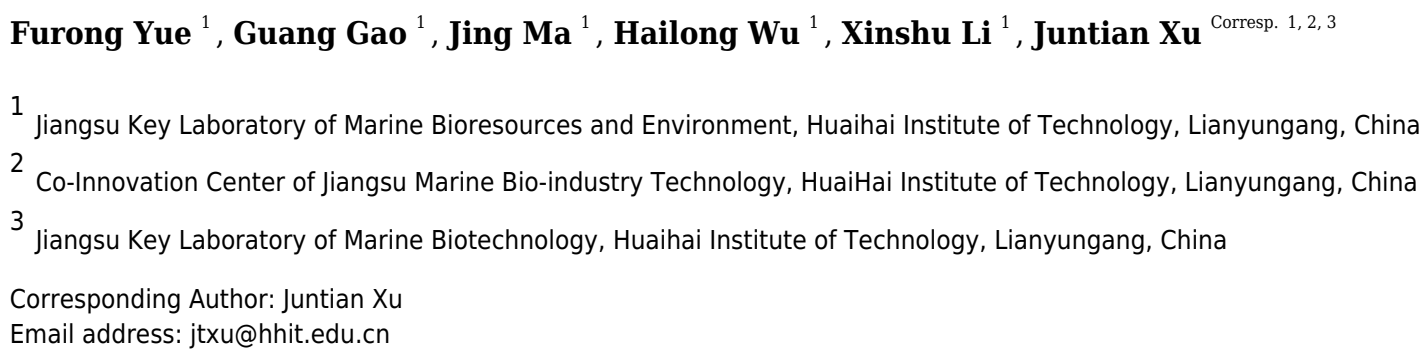

Photoperiods have an important impact on macroalgae living in the intertidal zone. Ocean acidification also influences the physiology of macroalgae. However, little is known about the interaction between ocean acidification and photoperiod on macroalgae. In this study, a green alga Ulva linza was cultured under three different photoperiods ( $L: D=8: 16$, $12: 12,16: 8$ ) and two different $\mathrm{CO}_{2}$ levels (LC, 400 ppm; $\mathrm{HC}, 1000$ ppm) to investigate their responses. The results showed that relative growth rate of $U$. linza increased with extended light periods under LC but decreased at $\mathrm{HC}$ when exposed to the longest light period of $16 \mathrm{hcompared}$ to $12 \mathrm{~h}$. Higher $\mathrm{CO}_{2}$ levels enhanced the relative growth rate at a $\mathrm{L}$ : D of 8:16, had no effect at 12:12 but reduced RGR at 16:8. At LC, the L: D of 16:8 significantly stimulated maximum quantum yield (Yield). Higher $\mathrm{CO}_{2}$ levels enhanced Yield at L: D of 12:12 and 8:16, had negative effect at 16:8. Non-photochemical quenching (NPQ) increased with increasing light period. High $\mathrm{CO}_{2}$ levels did not affect respiration rate during shorter light periods but enhanced it at a light period of $16 \mathrm{~h}$. Longer light periods had negative effects on $\mathrm{Chl} a$ and $\mathrm{Chl} b$ content, and high $\mathrm{CO}_{2}$ level also inhibited the synthesis of these pigments. Our data demonstrate the interactive effects of $\mathrm{CO}_{2}$ and photoperiod on the physiological characteristics of the green tide macroalga Ulva linza and indicate that future ocean acidification may hinder the stimulatory effect of long light periods on growth of Ulva species. 


\section{Future $\mathrm{CO}_{2}$-induced seawater acidification mediates}

3 the physiological performance of a green alga Ulva 4 linza in different photoperiods

5 Furong Yue ${ }^{1}$, Guang $\mathrm{Gao}^{1}$, Jing $\mathrm{Ma}^{1}$, Hailong $\mathrm{Wu}^{1}$, Xinshu $\mathrm{Li}^{1}$, Juntian $\mathrm{Xu}^{1,2,3 *}$

7 'Jiangsu Key Laboratory of Marine Bioresources and Environment, Huaihai Institute of

8 Technology, Lianyungang, 222005, China

$9{ }^{2}$ Co-Innovation Center of Jiangsu Marine Bio-industry Technology, Huaihai Institute of

10 Technology, Lianyungang, 222005, China

11 J Jiangsu Key Laboratory of Marine Biotechnology, Huaihai Institute of Technology,

12 Lianyungang, 222005, China

\section{${ }^{*}$ Corresponding author:}

Juntian $\mathrm{Xu}^{1}$

Cangwu Road 59, Lianyungang, Jiangsu, 222005, China

jtxu@hhit.edu.cn, Phone/Fax: +86 (0)518 85585003

\section{Abstract}

Photoperiods have an important impact on macroalgae living in the intertidal zone. Ocean acidification also influences the physiology of macroalgae. However, little is known about the interaction between ocean acidification and photoperiod on macroalgae. In this study, a green alga Ulva linza was cultured under three different photoperiods (L: $\mathrm{D}=8: 16,12: 12,16: 8)$ and two different $\mathrm{CO}_{2}$ levels ( $\mathrm{LC}, 400 \mathrm{ppm} ; \mathrm{HC}, 1000 \mathrm{ppm}$ ) to investigate their responses. The results showed that relative growth rate of $U$. linza increased with extended light periods under LC but decreased at HC when exposed to the longest light period of $16 \mathrm{~h}$ compared to $12 \mathrm{~h}$. Higher $\mathrm{CO}_{2}$ levels enhanced the relative growth rate at a L: D of 8:16, had no effect at 12:12 but reduced RGR at 16:8. At LC, the L: D of 16:8 significantly stimulated maximum quantum yield (Yield). Higher $\mathrm{CO}_{2}$ levels enhanced Yield at L: D of 12:12 and 8:16, had negative effect at 16:8. Non-photochemical quenching (NPQ) increased with increasing light period. High $\mathrm{CO}_{2}$ levels did not affect respiration rate during shorter light periods but enhanced it at a light period of $16 \mathrm{~h}$. Longer light periods had negative effects on $\mathrm{Chl} a$ and $\mathrm{Chl} b$ content, and high $\mathrm{CO}_{2}$ level also inhibited the synthesis of these pigments. Our data demonstrate the interactive effects of $\mathrm{CO}_{2}$ and 
photoperiod on the physiological characteristics of the green tide macroalga Ulva linza and indicate that future ocean acidification may hinder the stimulatory effect of long light periods on growth of Ulva species.

\section{Introduction}

Due to the activities of humans, the concentration of atmospheric $\mathrm{CO}_{2}$ has increased to $400 \mathrm{ppm}$ from 278 ppm during the pre-industrial revolution (Gattuso et al., 2015). It is estimated that the oceans, as a $\mathrm{CO}_{2}$ sink, have taken up approximately $48 \%$ of the fossil-fuel and cementmanufacturing emissions (Sabine et al., 2004). The concentration of atmospheric $\mathrm{CO}_{2}$ has been predicted to reach almost $1000 \mathrm{ppm}$ by the end of $21^{\text {st }}$ century (Gattuso et al., 2015). This would result in the decline of surface ocean $\mathrm{pH}$ by 0.3-0.4 units, an increase of hydrogen ion concentration and bicarbonate concentration in seawater, which is termed ocean acidification (OA) (Orr et al., 2005; Koch et al., 2013 Albright et al., 2016). OA will be maintained for hundreds of years, and thus could cause a huge change in marine ecosystems (Kroeker et al., 2013; Wittmann \& Pörtner, 2013).

Marine phytoplankton accounts for $50 \%$ of global primary production (Beardall et al., 2009) and macroalgae accounts for $10 \%$ of marine primary productivity (Smith, 1981; CharpyRoubaud \& Sournia, 1990; Heinrich et al., 2012). Macroalgae have evolved distinct strategies to capture inorganic carbon (Ci) for photosynthesis: (1) by the diffusive uptake of $\mathrm{CO}_{2}$ (Giordano \& Raven, 2005; Raven et al., 2005), (2) the active transport of $\mathrm{HCO}_{3}{ }^{-} / \mathrm{CO}_{2}$ (termed carbon concentrating mechanisms (CCMs) (Maberly et al., 1992; Raven, 2003; Giordano et al., 2005). The elevated $\mathrm{CO}_{2}$ might enhance the growth and photosynthesis of algae that depend on $\mathrm{CO}_{2}$ diffusion or have weak CCMs (Kübler et al., 1999; Gao et al., 2016a). Therefore, the physiological influences of OA on macroalgae might be species-specific. For example, OA has a positive influences on the growth of macroalgae, such as the red algae Pyropia yezoensis, Pyropia haitanensis and Gracilaria lemaneiformis (Gao et al., 1991; Xu \& Gao, 2015; Chen et al., 2018), green algae Ulva prolifera, Ulva lactuca, Caulerpa taxifolia (Xu \& Gao, 2012; Chen et al., 2015; Roth-Schulze et al., 2018) and brown algae Hizikia fusiforme, Ecklonia radiata, Sargassum muticum (Zou, 2005; Britton et al., 2016; Xu et al., 2017). However, research has shown that high $\mathrm{CO}_{2}$ levels did not have a detectable effect on the relative growth rate of several species, for example, Sargassum henslowianum, Ulva rigida, Ulva australis, the giant kelp Macrocystis pyrifera and Ulva australis (Chen \& Zou, 2014; Rautenberger et al., 2015; Fernández et al., 2015; Reidenbach et al., 2017). Furthermore, increasing seawater $\mathrm{CO}_{2}$ concentration reduced the growth of Gracilaria tenuistipitata, Porphyra leucosticte, Fucus vesiculosus, Halimeda opuntia and Ulva linza (García-Sánchez et al., 1994; Mercado et al., 1999; Gutow et al., 2014; Johnson et al., 2014; Gao et al., 2018). In addition, the various effects of 
ocean acidification may be also modulated by other environmental factors, such as temperature, nutrients and photoperiods (Gao et al., 2017a; Gao et al., 2019; Li et al., 2018).

Photoperiod is a key factor regulating seasonal responses of algae (Dring, 1998). Furthermore, daylength can influence algal affinity for dissolved inorganic carbon and cellular carbon demand, thus imposing an effect on CCMs regulation (Rost et al., 2006). Thus, the photoperiod may be critical for algae cultured under elevated $\mathrm{CO}_{2}$ levels. Meanwhile, the interactive effects of $\mathrm{OA}$ and increased photoperiods could enhance the growth of $U$. prolifera, thus increase the opportunities for occurrence of green tides (Li et al., 2018). Elevated $\mathrm{CO}_{2}$ levels enhanced the photosynthetic rate, but longer illumination periods reduced the photosynthetic efficiency in E. huxleyi (Nielsen, 1997; Rost et al., 2006). Therefore, at HC, the responses of algae to different photoperiods appear to be genera- and species-specific.

Green macroalgal bloom has occurred each year in the Yellow Sea (YS) since 2007, termed green tides (Xu et al., 2016). Green tides generate aesthetic problems and toxic gas when thalli decompose (Gao et al., 2016b). Ulva is the dominant genus contributing majority of green tides and $U$. linza is one of species causing green tides in the Yellow Sea (Fletcher, 1996; Kang et al., 2014; Gao et al., 2017a, b). However, little is known about the interactive effects of ocean acidification and photoperiod on $U$. linza. Previous study showed that the effect of ocean acidification on diatoms was related to light intensity (Gao et al., 2012). In this study, based on previous studies, we hypothesized the effect of ocean acidification on $U$. linza may dependent on photoperiod. To test our hypothesis, the physiological responses of the green macroalga Ulva linz $a$ under two different $\mathrm{CO}_{2}$ levels and three different photoperiods were examined.

\section{Materials \& Methods}

\section{Thalli collection and culture conditions}

U. linza was collected from the coastal water of Gaogong peninsula $\left(119.3^{\circ} \mathrm{E}, 34.5^{\circ} \mathrm{N}\right)$, Lianyungang, Jiangsu Province, China. Gaogong peninsula is a public place and no approval is required for collecting naturally growing Ulva species in China because Ulva species cause green tides in coastal waters of the Yellow Sea. U. linza was identified by morphological characters (Ma et al., 2009). The samples were transferred to the laboratory in a portable cooler $\left(4-6^{\circ} \mathrm{C}\right.$ ) box within one hour. Healthy thalli (first observed by color and then checked with maximum quantum yield of PSII) were selected and cleaned with filtered natural seawater to remove sediments, visible epiphytes and attached animals. Thalli were pre-cultured in a $500 \mathrm{ml}$ flask in an illuminated incubator (GXZ-500B, Ningbo, China) at $20^{\circ} \mathrm{C}$, with the illumination intensity set at $150 \mu \mathrm{mol}$ photons $\mathrm{m}^{-2} \mathrm{~s}^{-1}$ (12L:12D). Sterilized filtered seawater (salinity 30, 
102 supplied with $8 \mu \mathrm{M} \mathrm{NaH} \mathrm{PO}_{4}$ and $60 \mu \mathrm{M} \mathrm{NaNO}$ ) was used as culture medium and the medium 103 was bubbled with air before being renewed every two days.

104 For these experiments, approximately three $1 \mathrm{~cm}$ long thalli were placed into a $550 \mathrm{ml}$ flask filled with $500 \mathrm{ml}$ sterile seawater aerated ambient outdoor air (400 ppm, LC) or with $\mathrm{CO}_{2}$ enriched air (1000 ppm, HC) and randomly cultured in three separate incubators with different light levels (8L:16D, 12L:12D, 16L:8D) and continuous aeration at $20^{\circ} \mathrm{C}$ with $150 \mu \mathrm{mol}$ photons $\mathrm{m}^{-2} \mathrm{~s}^{-1}$. Different $\mathrm{CO}_{2}$ levels (400 ppm, LC; $1000 \mathrm{ppm}, \mathrm{HC}$ ) were achieved by bubbling ambient air or $\mathrm{CO}_{2}$-enriched air via a $\mathrm{CO}_{2}$ plant incubator (HP $1000 \mathrm{G}-\mathrm{D}$, Ruihua Instruments, Wuhan, China).

111 To maintain the $\mathrm{pH}_{\mathrm{NBS}}$ at about 8.12 (LC) and 7.78 (HC) under different photoperiods, the increased algal biomass were removed constantly and the medium was changed every two days and daily variations in $\mathrm{pH}$ were maintained at less than 0.05 . The experiment lasted 9 days, the physiological factors were taken on the last 3 days.

\section{Estimate of carbonate system parameters}

The seawater $\mathrm{pH}$ was monitored with a $\mathrm{pH}$ meter ( $\mathrm{pH} 700$, Eutech Instruments, Singapore) and total alkalinity (TA) was calculated by titrations (Gao et al., 2019). Other parameters of the carbonate system were obtained with CO2SYS software (Pierrot et al., 2006), the equilibrium constants $\mathrm{K}_{1}$ and $\mathrm{K}_{2}$ for carbonic acid dissociation (Roy et al., 1993).

\section{Measurement of growth}

The length of $U$. linza was recorded every 2 days. The relative growth rate (RGR) of thalli were calculated across the 6-day period before other physiological parameters were measured during the following 3 days. RGR was calculated as follows: $R G R=\ln \left(\mathrm{W}_{\mathrm{t}} / \mathrm{W}_{0}\right) / \mathrm{t}$, where $\mathrm{W}_{\mathrm{t}}$ is the length after $t$ days culture, $\mathrm{W}_{0}$ is the initial length.

\section{Chlorophyll fluorescence measurements}

127

128

129

130

131

132

133

134

Chlorophyll $a$ fluorescence in $U$. linza was measured with a portable PAM (Pulse-amplitudemodulation; AquaPen-P AP-P 100, Chech). Algae were dark adapted for 15 min before the experiment. The parameters were calculated according to the following equations: $\mathrm{rETR}=\mathrm{PAR} \times \mathrm{Y}(\mathrm{II}) \times 0.84 \times 0.5($ Schreiber, 2004; Zhang et al., 2017), where rETR is the relative electron transport rate; PAR is the actinic light; Y(II) is the maximum quantum yield of PSII. $\mathrm{NPQ}=\mathrm{Fm}-\mathrm{Fm}$ '/1 (Bilger \& Schreiber, 1986), where NPQ is the non-photochemical quenching; Fm is the maximum fluorescence value of $U$. 
135 linza when they were adapted in the dark for $15 \mathrm{~min}$; Fm' is the maximum fluorescence value of 136 U. linza under actinic light conditions.

\section{Respiration rate measurements}

138 The respiration rate of $U$. linza was measured using a Clark-type oxygen electrode (YSI Model 5300, Yellow Springs Instrument Co., USA). The thallus was cut into $1 \mathrm{~cm}$ long segments with scissors and the thalli were placed in culture conditions for at least $1 \mathrm{~h}$ to decrease the effects of cutting damage. Approximately $0.01 \mathrm{~g}$ fresh weight of thalli were placed in the reaction chamber with $8 \mathrm{ml}$ medium. Temperature was controlled at $20{ }^{\circ} \mathrm{C}$ with a circulating water bath. The decrease of the oxygen content in the seawater in darkness with seven minutes was defined as the respiration rate.

\section{Measurement of photosynthetic pigments}

Chlorophyll $a$ and $b$ were extracted from thalli (about $10 \mathrm{mg} \mathrm{FW}$ ) with $5 \mathrm{ml}$ methanol at $4{ }^{\circ} \mathrm{C}$ for $24 \mathrm{~h}$ in the dark. The absorption values were obtained at $652 \mathrm{~nm}, 663 \mathrm{~nm}$ and $665 \mathrm{~nm}$ using an ultraviolet spectrophotometer (Ultrospect 3300 pro, Amersham Bioscience, Sweden). The contents of the Chl $a$ and Chl $b$ were estimated using the method of Porra (1989).

\section{Data analysis}

All the data are shown as mean \pm SD. Origin 9.0 and SPSS 18.0 were used to analyze data. Twoway ANOVA was used to assess the interactive effects of $\mathrm{CO}_{2}$ levels and photoperiods on relative growth rate, chlorophyll fluorescence parameters, respiration rate and pigment content of $U$. linza. One-way ANOVA was used to analyze differences under the same conditions. Tukey HSD was conducted for post hoc investigation. Confidence intervals were set at $95 \%$.

\section{Results}

Both the elevated $\mathrm{CO}_{2}$ levels and photoperiod altered carbonate parameters in seawater, and they both had an interactive effect (Tables 1 and 2). The elevated $\mathrm{CO}_{2}$ decreased $\mathrm{pH}$ and $\mathrm{CO}_{3}{ }^{2-}$, increased $p \mathrm{CO}_{2}, \mathrm{DIC}, \mathrm{HCO}_{3}{ }^{-}$and $\mathrm{CO}_{2}$ in the seawater. Increased photoperiod did not affect carbonate parameters at $\mathrm{LC}$ but the longest photoperiod increased $\mathrm{DIC}, \mathrm{HCO}_{3}{ }^{-}$and $\mathrm{TA}$ compared to shortest photoperiod.

The two-way ANOVA showed that elevated $\mathrm{CO}_{2}$ and photoperiod had an interactive effect, and both elevated $\mathrm{CO}_{2}$ levels and the photoperiods had a significant effect on the RGR of $U$. linza (Fig. 1 and Table 3). At LC, the RGR of adult $U$. linza increased with the extended light periods, and the highest RGR occurred at a L: D of 16:8. The effect of $\mathrm{CO}_{2}$ also varied with photoperiod. Higher $\mathrm{CO}_{2}$ levels enhanced RGR at L: D of 8:16, but had no effect at 12:12 and reduced it at 16:8. 
The Yield and NPQ were measured under different $\mathrm{CO}_{2}$ levels and photoperiod conditions (Fig. 2). Two-way ANOVA showed that elevated $\mathrm{CO}_{2}$ and photoperiod had an interactive effect on Yield (Table 4). Higher $\mathrm{CO}_{2}$ levels increased Yield when thalli were cultured under photoperiods of 8:16 and 12:12 but reduced it under 16:8. Photoperiod had the main effect on NPQ (Table 4). At LC, thalli cultured at L: D of 16:8 had higher NPQ compared to L: D of 8:16 while the difference between 8:16 and 12:12 was insignificant. At HC, NPQ increased with the increase in photoperiod although the increase was not statistically significant. The elevated $\mathrm{CO}_{2}$ had neutral effect on NPQ of $U$. linza.

Maximum rETR (rETRmax), efficiency of electron transport $(\alpha)$, and saturating irradiance $\left(\mathrm{I}_{\mathrm{k}}\right)$ were calculated from the rapid light curves (Fig. 3, Table 5). Photoperiod and elevated $\mathrm{CO}_{2}$ levels had an interactive effect, and elevated $\mathrm{CO}_{2}$ levels had a main effect on light-saturated electron transport rate (rETRmax) (Table 6). Higher $\mathrm{CO}_{2}$ levels increased rETRmax during the 8:16 and 12:12 photoperiods, but did not affect it at 16:8. A similar pattern was also found for $\alpha$. In contrast to rETRmax and $\alpha, \mathrm{CO}_{2}$ did not affect $\mathrm{I}_{\mathrm{k}}$ while photoperiod had the main effect on it. At LC, $\mathrm{I}_{\mathrm{k}}$ increased when $\mathrm{L}$ : $\mathrm{D}$ rose from 8:16 to $12: 12$ but did not change with the further increase in photoperiod. At $\mathrm{HC}, \mathrm{I}_{\mathrm{k}}$ did not change when $\mathrm{L}$ : D rose from 8:16 to 12:12 but was enhanced when L: D increased to 16:8 (Table 5).

In addition to photosynthetic parameters, the effects of $p \mathrm{CO}_{2}$ and photoperiod on the respiration rate of adult $U$. linza were also investigated (Fig. 4). Photoperiod and elevated $\mathrm{CO}_{2}$ levels had an interactive effect, and both photoperiod and elevated $\mathrm{CO}_{2}$ levels had the primary effect on the respiration rate of $U$. linza (Table 7). Higher $\mathrm{CO}_{2}$ levels did not affect the respiration rate at photoperiods of $8: 16$ or $12: 12$ but increased it by $56.39 \%$ at a photoperiod of $16: 8$.

Changes in photosynthetic pigments of $U$. linza grown under various conditions are shown in Fig. 5. Two-way ANOVA showed that $\mathrm{CO}_{2}$ and photoperiod had an interactive effect, and both $\mathrm{CO}_{2}$ levels and the photoperiods had the main effect on the Chl $a$ content of $U$. linza (Table 8). Prolonged light periods reduced the synthesis of $\mathrm{Chl} a$ in thalli although the difference between the photoperiods of 8:16 and 12:12 at $\mathrm{HC}$ was not statistically significant. Higher $\mathrm{CO}_{2}$ levels reduced Chl $a$ at the photoperiods of 8:16 and 12:12 but did not affect it at a L: D of 12:12. The same trend was found for $\mathrm{Chl} b$. The $\mathrm{Chl} a / b$ ratios were all greater than 1.0, suggesting a higher synthesis of Chl $a$ than $\mathrm{Chl} b$ under all culture conditions. Photoperiod and elevated $\mathrm{CO}_{2}$ levels had an interactive effect on the $\mathrm{Chl} a / b$ ratio (Table 8); the higher $\mathrm{CO}_{2}$ levels increased the ratio at a photoperiod of 12:12 but not at the other photoperiods.

\section{Discussion}

In the present study, at LC, extended photoperiods had a positive effect on the relative growth rate of adult $U$. linza, similar to previous studies on Laminaria sacharina, Porphyra umbilicalis 
204

205

206

207

208

209

210

211

212

213

214

215

216

217

218

219

220

221

222

223

224

225

226

227

228

229

230

231

232

233

234

235

236

237

238

239

and Ulva prolifera (Fortes \& Lüning,1980; Green \& Neefus, 2016; Li et al., 2018). Carbon isotope fractionation experiments suggested that extended photoperiods could enhance growth by influencing inorganic carbon capture and fixation rate in algae (Rost et al., 2003). This hypothesis is supported by the present study where extended photoperiods increased the maximum quantum yield in PS II. On the other hand, the highest growth rates of Compsopogon coeruleus were obtained in shorter light periods (L: $\mathrm{D}=8: 16)$ (Zucchi \& Necchi, 2001), the highest growth rates of Porphyra umbilicalis was found under neutral (L: $\mathrm{D}=12: 12$ ) and longer $(\mathrm{L}: \mathrm{D}=16: 8)$ light periods using $110 \mu \mathrm{mol}$ photons $\mathrm{m}^{-2} \mathrm{~s}^{-1}$ (Green \& Neefus, 2016), and the relative growth rate of Chlorella vulgaris cultured at L: D $=20: 4$ was lower than the RGR of alga cultured at L: $\mathrm{D}=16: 8$ (Kendirlioglu et al., 2015). Therefore, the effects of photoperiod on algae appear to be species-specific.

Although Ulva has efficient mechanisms for $\mathrm{CO}_{2}$ concentration, the growth of Ulva can be enhanced by elevated $\mathrm{CO}_{2}$ (Young et al., 2016; Gao et al., 2016a, 2017). However, in this study, we found that the effects of elevated $\mathrm{CO}_{2}$ levels on the relative growth rate of $U$. linza depended on photoperiod. $\mathrm{CO}_{2}$ enhanced the growth of adult $U$. linza under light/dark conditions of 8:16, had no effect on growth of $U$. linza under a $\mathrm{L}$ : $\mathrm{D}$ of 12:12, and reduced the relative growth rate under a L: D of 16:8. High $\mathrm{CO}_{2}$ levels can down-regulate algal $\mathrm{CO}_{2}$ concentration mechanisms (CCMs), meaning that energy would be saved, and thus enhancing the relative growth rate of algae (Gao et al., 2012, 2016a; Raven et al., 2017). This is supported by decreased pigment synthesis in thalli at higher $\mathrm{CO}_{2}$ levels. However, higher $\mathrm{CO}_{2}$ levels did not affect the growth rate of $U$. linza at medium photoperiods. The neutral effects of $\mathrm{CO}_{2}$ on the growth of $U$. rigida (Rautenberger et al., 2015) and $U$. linza (Gao et al., 2018) were also reported. We speculate that this is a compromise between the positive effects of elevated $\mathrm{CO}_{2}$ and negative effects of decreased $\mathrm{pH}$. The negative effect of decreased $\mathrm{pH}$ on growth was documented for the brown alga Sargassum muticum (Xu et al., 2017). Algae might need to consume additional energy to act against acid-based perturbation caused by decreased $\mathrm{pH}$, leading to reduced growth (Xu et al., 2017). This is supported by an enhanced respiration rate at the higher $\mathrm{CO}_{2}$ levels in this study. The phenomenon of an increased respiration rate of algae under elevated $\mathrm{CO}_{2}$ concentrations was found in Hizikia fusiformis (Zou et al., 2005), the microalgae Phaeodactylum tricornutum (Wu et al., 2010) and Emiliania huxleyi (Jin et al., 2015).

Furthermore, the higher $\mathrm{CO}_{2}$ level reduced the growth rate of $U$. linza under the longest photoperiod in the present study. This may be due to the combination of down-regulated CCMs and excess light energy. The operation of CCMs is an energy-consuming process and the downregulation of CCMs can result in additional energy (Raven et al., 2017). Higher light can usually reduce algal photosynthetic activity (Singh and Singh, 2015; Gao et al., 2016a). The energy saved due to down-regulation of CCMs at $\mathrm{HC}$ combined with high light intensity could 
240

241

242

243

244

245

246

247

248

249

250

251

252

253

254

255

256

257

258

259

260

261

262

263

264

265

266

267

268

269

270

271

272

273

synergistically damage the algal photosystem and photosynthetic rate (Gao et al., 2012, 2016a). Although light intensity did not change among different $\mathrm{CO}_{2}$ treatments, the lengthened photoperiod may have similar effect to increased light intensity. This argument is supported by increased NPQ at longer photoperiods as NPQ is photo-protective process to dissipate excess light energy. Higher $\mathrm{CO}_{2}$ levels also reduced maximum quantum yield and stimulated the respiration rate of $U$. linza during the longest photoperiod in this study, leading to the decrease in growth. Enhanced respiration rate is a signal that organisms are fighting against stress and damage (Xu et al., 2017).

In addition to growth, the interactive effect of $\mathrm{CO}_{2}$ and photoperiod was also found in photosynthetic parameters. For instance, elevated $\mathrm{CO}_{2}$ increased Yield, rETRmax and $\alpha$ at shorter photoperiods (L: D of 8:16 and 12:12) but did not affect rETRmax and reduced Yield at longest photoperiod (L: D of 16:8). These findings indicate the close connection between growth and photosynthesis in terms of responding to the combination of $\mathrm{CO}_{2}$ and photoperiod. It is worth noting that the interaction of $\mathrm{CO}_{2}$ and photoperiod on growth of $U$. linza in this study is different from the findings in $U$. prolifera reported by Li et al (2018). Elevated $\mathrm{CO}_{2}$ increased growth of $U$. prolifera at all three photoperiods (L: D of 12:12, 10:14 and 16:8). The different results may be due to differential physiological property between $U$. linza and $U$. prolifera. It has been documented that $U$. prolifera has a higher tolerance to high light intensity compared to $U$. linza (Cui et al., 2015). The strong capacity in dealing with high light intensity could contribute to the effect of elevated $\mathrm{CO}_{2}$ and prolonged photoperiod on growth $U$. linza was still positive. Integrating our findings with $\mathrm{Li}$ et al's (2018) study, the interaction of $\mathrm{CO}_{2}$ and photoperiod on Ulva species would be species dependent.

\section{Conclusions}

This work is the first attempt to clarify the interaction between light/dark and elevated $\mathrm{CO}_{2}$ levels on the physiological responses of Ulva linza. We found that the effect of OA on U. linza depended on photoperiod. Outbreaks of green tides during spring and summer in China occur when the photoperiod is reaching its peak. Our findings indicate future OA may hinder the occurrence of green tides dominated by $U$. linza in combination with extended photoperiods. More environmental factors, such as temperature and nutrient levels, need to be investigated to obtain a more comprehensive understanding on development of green tides in future oceans.

\section{Acknowledgements}




\section{References}

277

Albright R. 2016. Reversal of ocean acidification enhances net coral reef calcification. Nature 531:362-365 DOI 10.1038/nature17155.

Beardall J, Stojkovic S, Larsen S. 2009. Living in a high $\mathrm{CO}_{2}$ world: impacts of global climate change on marine phytoplankton. Plant Ecology \& Diversity 2:191-205 DOI 10.1080/17550870903271363.

Bilger W, Schreiber U. 1986. Energy-dependent quenching of dark-level chlorophyll fluorescence in intact leaves. Photosynthesis Research 10:303-308 DOI 10.1007/bf00118295.

Britton D, Cornwall CE, Revill AT, Hurd CL, Johnson CR. 2016. Ocean acidification reverses the positive effects of seawater $\mathrm{pH}$ fluctuations on growth and photosynthesis of the habitatforming kelp, Ecklonia radiata. Scientific Reports 6:26036 DOI 10.1038/srep26036.

Charpy-Roubaud C, Sournia A. 1990. The comparative estimation of phytoplanktonic, microphytobenthic and macrophytobenthic primary production in the oceans. Marine Microbial Food Webs 4:31-57

Chen B, Zou D. 2014. Growth and photosynthetic activity of Sargassum henslowianum (Fucales, Phaeophyta) seedlings in responses to different light intensities, temperatures and $\mathrm{CO}_{2}$ levels under laboratory conditions. Marine Biology Research 10:1019-1026 DOI 10.1080/17451000.2013.872798.

Chen B, Zou D, Jiang H. 2015. Elevated $\mathrm{CO}_{2}$ exacerbates competition for growth and photosynthesis between Gracilaria lemaneiformis and Ulva lactuca. Aquaculture 443:49-55 DOI 10.1016/j.aquaculture.2015.03.009.

Chen B, Zou D, Du H, Ji Z. 2018. Carbon and nitrogen accumulation in the economic seaweed Gracilaria lemaneiformis affected by ocean acidification and increasing temperature. Aquaculture 482:176-182 DOI 10.1016/j.aquaculture.2017.09.042.

Cui J, Zhang J, Huo Y, Zhou L, Wu Q, Chen L, Yu K, He P, 2015. Adaptability of free-floating green tide algae in the Yellow Sea to variable temperature and light intensity. Marine Pollution Bulletin 101:660-666

DOI 10.1016/j.marpolbul.2015.10.033.

Dring MJ. 1988. Photocontrol of development in algae. Annual Review of Plant Physiology and Plant Molecular Biology 39:157-174 DOI 10.1146/annurev.pp.39.060188.001105. 
308 Fernández PA, Roleda MY, Hurd CL. 2015. Effects of ocean acidification on the photosynthetic performance, carbonic anhydrase activity and growth of the giant kelp Macrocystis pyrifera. Photosynthesis Research 124:293-304 DOI 10.1007/s11120-015-0138-5.

Fletcher RL. 1996. The occurrence of "green tides"-a review. In Marine benthic vegetation (pp. 7-43) Springer, Berlin, Heidelberg. DOI 10.1007/978-3-642-61398-2_2.

Fortes MD, Lüning K. 1980. Growth rates of North Sea macroalgae in relation to temperature, irradiance and photoperiod. Helgoländer Meeresuntersuchungen 34:15-29 DOI 10.1007/BF01983538.

Gao G, Clare AS, Rose C, Caldwell GS. 2017a. Eutrophication and warming-driven green tides (Ulva rigida) are predicted to increase under future climate change scenarios. Marine Pollution Bulletin 114:439-447 DOI 10.1016/j.marpolbul.

Gao G, Beardall J, Bao M, Wang C, Ren W, Xu J. 2018. Ocean acidification and nutrient limitation synergistically reduce growth and photosynthetic performances of a green tide alga Ulva linza. Biogeosciences 15:3409-3420

DOI 10.5194/bg-15-3409-2018.

Gao G, Gao Q, Bao M, Xu J, Li X. 2019. Nitrogen availability modulates the effects of ocean acidification on biomass yield and food quality of a marine crop Pyropia yezoensis. Food Chemistry 271:623-629

DOI 10.1016/j.foodchem.2018.07.090.

Gao G, Liu Y, Li X, Feng Z, Xu J. 2016a. An ocean acidification acclimatized green tide alga is robust to changes of seawater carbon chemistry but vulnerable to light stress. PloS one 11:e0169040 DOI 10.1371/journal.pone.0169040.

Gao G, Liu Y, Li X, Feng Z, Xu Z, Wu H, Xu J. 2017b. Expected $\mathrm{CO}_{2}$-induced ocean acidification modulates copper toxicity in the green tide alga Ulva prolifera. Environmental and Experimental Botany 135:63-72

DOI 10.1016/j.envexpbot.2016.12.007.

Gao G, Zhong Z, Zhou X, Xu J. 2016b. Changes in morphological plasticity of Ulva prolifera under different environmental conditions: a laboratory experiment. Harmful Algae 59:51-58 DOI 10.1016/j.hal.2016.09.004.

Gao K, Aruga Y, Asada K, Ishihara T, Akano T, Kiyohara M. 1991. Enhanced growth of the red alga Porphyra yezoensis Ueda in high $\mathrm{CO}_{2}$ concentrations. Journal of Applied Phycology 3:355-362 DOI 10.1007/bf02392889.

Gao K, Xu J, Gao G, Li Y, Hutchins DA, Huang B. 2012. Rising $\mathrm{CO}_{2}$ and increased light exposure synergistically reduce marine primary productivity. Nature Climate Change 
2:519-523 DOI 10.1038/nclimate1507.

Gao Z, Xu D, Meng C, Zhang X, Wang Y, Li D. 2014. The green tide-forming macroalga Ulva linza outcompetes the red macroalga Gracilaria lemaneiformis via allelopathy and fast nutrients uptake. Aquatic Ecology 48:53-62

DOI 10.1007/s10452-013-9465-9.

García-Sánchez MJ, Fernández JA, Niell X. 1994. Effect of inorganic carbon supply on the photosynthetic physiology of Gracilaria tenuistipitata. Planta 194:55-61 DOI 10.1007/bf00201034.

Gattuso JP, Magnan A, Billé R, Cheung WW, Howes EL, Joos F. 2015. Contrasting futures for ocean and society from different anthropogenic $\mathrm{CO}_{2}$ emissions scenarios. Science 349:aac4722 DOI 10.1126/science.aac4722.

Giordano M, Beardall J, Raven JA. 2005. $\mathrm{CO}_{2}$ concentrating mechanisms in algae: mechanisms, environmental modulation, and evolution. Annual Review Plant Biology 56:99-131 DOI 10.1146/annurev.arplant.56.032604.144052.

Green LA, Neefus CD. 2016. Effects of temperature, light level, and photoperiod on the physiology of Porphyra umbilicalis Kützing from the Northwest Atlantic, a candidate for aquaculture. Journal of Applied Phycology 28:1815-1826

DOI 10.1007/s10811-015-0702-6.

Gutow L, Rahman MM, Bartl K, Saborowski R, Bartsch I, Wiencke C. 2014. Ocean acidification affects growth but not nutritional quality of the seaweed Fucus vesiculosus (Phaeophyceae, Fucales). Journal of Experimental Marine Biology and Ecology 453:84-90 DOI 10.1016/j.jembe.2014.01.005.

Heinrich S, Valentin K, Frickenhaus S, John U, Wiencke C. 2012. Transcriptomic analysis of acclimation to temperature and light stress in Saccharina latissima (Phaeophyceae). PLoS one 7: e44342 DOI 10.1371/journal.pone.0044342.

Jin P, Wang T, Liu N, Dupont S, Beardall J, Boyd PW. 2015. Ocean acidification increases the accumulation of toxic phenolic compounds across trophic levels. Nature Communications 6:8714 DOI 10.1038/ncomms9714.

Johnson MD, Price NN, Smith JE. 2014. Contrasting effects of ocean acidification on tropical fleshy and calcareous algae. PeerJ 2:e411 DOI 10.7717/peerj.411.

Kang EJ, Kim JH, Kim K, Choi HG, Kim KY. 2014. Re-evaluation of green tide-forming species in the Yellow Sea. Algae 29:49-59 DOI 10.4490/algae.2016.31.3.9.

Kendirlioglu G, Agirman N, Cetin A. 2015. The effects of photoperiod on the growth, protein amount and pigment content of Chlorella vulgaris. Turkish Journal of Science \& Technology 10:7-10.

Kim JH, Kang EJ, Park MG, Lee BG, Kim KY. 2011. Effects of temperature and irradiance on 
photosynthesis and growth of a green-tide-forming species (Ulva linza) in the Yellow Sea. Journal of Applied Phycology 23:421-432

DOI 10.1007/s10811-010-9590-y.

Koch M, Bowes G, Ross C, Zhang XH. 2013. Climate change and ocean acidification effects on seagrasses and marine macroalgae. Global Change Biology 19:103-132 DOI 10.1111/j.1365-2486.2012.02791.x.

Kroeker KJ, Kordas RL, Crim R, Hendriks IE, Ramajo L, Singh GS. 2013. Impacts of ocean acidification on marine organisms: quantifying sensitivities and interaction with warming. Global Change Biology 19:1884-1896 DOI 10.1111/gcb.12179.

Kübler JE, Johnston AM, Raven JA. 1999. The effects of reduced and elevated $\mathrm{CO}_{2}$ and $\mathrm{O}_{2}$ on the seaweed Lomentaria articulata. Plant, Cell \& Environment 22: 1303-1310 DOI 10.1046/j.1365-3040.1999.00492.x.

Li Y, Zhong J, Zheng M, Zhuo P, Xu N. 2018. Photoperiod mediates the effects of elevated $\mathrm{CO}_{2}$ on the growth and physiological performance in the green tide alga Ulva prolifera. Marine Environmental Research 141:24-29

DOI 10.1016/j.marenvres.2018.07.015.

Ma J, J J, Xu R, He P, Zhang T, Wang X, Li Y, Ren S, Xu P, Lu Q. 2009. Preliminary study on life history of Ulva linza Linnaeus [Enteromorpha linza (L.) J. Ag.]. Journal of Fisheries of China 1 33:45-52Maberly SC, Raven JA, Johnston AM. 1992. Discrimination between ${ }^{12} \mathrm{C}$ and ${ }^{13} \mathrm{C}$ by marine plants. Oecologia 91:481-492 DOI 10.1007/bf00650320.

Mercado JM, Javier F, Gordillo L, Niell FX, Figueroa FL. 1999. Effects of different levels of $\mathrm{CO}_{2}$ on photosynthesis and cell components of the red alga Porphyra leucosticta. Journal of Applied Phycology 11:455-461

DOI 10.1023/A: 1008194223558.

Nielsen MV. 1997. Growth, dark respiration and photosynthetic parameters of the coccolithophorid Emiliania Huxleyi (Prymnesiophyceae) acclimated to different day lengthirradiance combinations1. Journal of Phycology 33:818-822 DOI 10.1111/j.0022-3646.1997.00818.x.

Orr JC, Fabry VJ, Aumont O, Bopp L, Doney SC, Feely RA. 2005. Anthropogenic ocean acidification over the twenty-first century and its impact on calcifying organisms. Nature 437:681-686 DOI 10.1038/nature04095.

Pierrot D, Lewis E, Wallace DWR. 2006. MS Excel program developed for $\mathrm{CO}_{2}$ system calculations. ORNL/CDIAC-105a. Carbon Dioxide Information Analysis Center, Oak Ridge National Laboratory, US Department of Energy, Oak Ridge, Tennessee.

Porra RJ, Thompson WA, Kriedemann PE. 1989. Determination of accurate extinction coefficients and simultaneous equations for assaying chlorophylls $a$ and $b$ extracted with 
four different solvents: verification of the concentration of chlorophyll standards by atomic absorption spectroscopy. Biochimica et Biophysica Acta (BBA)-Bioenergetics 975:384-394 DOI 10.1016/S0005-2728(89)80347-0.

Rautenberger R, Fernandez PA, Strittmatter M, Heesch S, Cornwall CE, Hurd CL, Roleda MY. 2015. Saturating light and not increased carbon dioxide under ocean acidification drives photosynthesis and growth in Ulva rigida (Chlorophyta). Ecology and Evolution 5:874-888 DOI 10.1002/ece3.1382.

Raven JA. 2003. Inorganic carbon concentrating mechanisms in relation to the biology of algae. Photosynthesis Research 77:155-171 DOI 10.1023/A:1025877902752.

Raven JA, Ball LA, Beardall J, Giordano M, Maberly SC. 2005. Algae lacking carbonconcentrating mechanisms. Canadian Journal of Botany 83: 879-890 DOI 10.1139/b05-074.

Raven JA, Beardall J, Sánchez-Baracaldo P. 2017. The possible evolution and future of $\mathrm{CO}_{2}$ concentrating mechanisms. Journal of Experimental Botany 68:3701-3716 DOI 10.1093/jxb/erx110.

Reidenbach LB, Fernandez PA, Leal PP, Noisette F, McGraw CM, Revill AT, 2017. Growth, ammonium metabolism, and photosynthetic properties of Ulva australis (Chlorophyta) under decreasing $\mathrm{pH}$ and ammonium enrichment. PloS one 12:e0188389 DOI 10.1371/journal.pone.0188389.

Rost B, Riebesell U, Burkhardt S, Sültemeyer D. 2003. Carbon acquisition of bloom-forming marine phytoplankton. Limnology and Oceanography 48:55-67

DOI 10.4319/1o.2003.48.1.0055.

Rost B, Riebesell U, Sültemeyer D. 2006. Carbon acquisition of marine phytoplankton: effect of photoperiod length. Limnology and Oceanography 51:12-20 DOI 10.4319/lo.2006.51.1.0012.

Roth-Schulze AJ, Thomas T, Steinberg P, Deveney MR, Tanner JE, Wiltshire KH. 2018. The effects of warming and ocean acidification on growth, photosynthesis, and bacterial communities for the marine invasive macroalga Caulerpa taxifolia. Limnology and Oceanography 63:459-471 DOI 10.1002/lno.10739.

Roy RN, Roy LN, Vogel KM, Porter-Moore C, Pearson T, Good CE, Millero FJ, Campbell DM. 1993. The dissociation constants of carbonic acid in seawater at salinities 5 to 45 and temperatures 0 to 45 C. Marine Chemistry 6: 249-267 DOI 10.1016/0304-4203(93)90207-5.

Sabine CL, Feely RA, Gruber N, Key RM, Lee K, Bullister JL. 2004. The oceanic sink for anthropogenic $\mathrm{CO}_{2}$. Science 305:367-371

DOI 10.1126/science.1097403. 
451

452

453

454

455

456

457

458

459

460

461

462

463

464

465

466

467

468

469

470

471

472

473

474

475

476

477

478

479

480

481

482

483

484

485

486

Schreiber U. 2004. Pulse-amplitude-modulation (PAM) fluorometry and saturation pulse method: an overview. Chlorophyll a Fluorescence 19:279-319 DOI 10.1007/978-1-4020-3218-9_11.

Singh SP, Singh P. 2015. Effect of temperature and light on the growth of algae species: a review. Renewable and Sustainable Energy Reviews 50:431-444 DOI 10.1016/j.rser.2015.05.024.

Smith, SV. 1981. Marine macrophytes as a global carbon sink. Science 211:838-840 DOI 10.1126/science.211.4484.838.

Wittmann AC, Pörtner HO. 2013. Sensitivities of extant animal taxa to ocean acidification. Nature Climate Change 3:995-1001 DOI 10.1038/nclimate1982.

Wu Y, Gao K, Riebesell U. 2010. $\mathrm{CO}_{2}$-induced seawater acidification affects physiological performance of the marine diatom Phaeodactylum tricornutum. Biogeosciences 7:29152923 DOI 10.5194/bg-7-2915-2010.

$\mathrm{Xu} \mathrm{J}$, Gao K. 2012. Future $\mathrm{CO}_{2}$-induced ocean acidification mediates the physiological performance of a green tide alga. Plant Physiology 160:1762-1769 DOI 10.1104/pp.112.206961.

Xu J, Gao K. 2015. Photosynthetic performance of the red alga Pyropia haitanensis during emersion, with special reference to effects of solar UV radiation, dehydration and elevated $\mathrm{CO}_{2}$ concentration. Photochemistry and Photobiology 91:1376-1381 DOI 10.1111/php.12531.

Xu Q, Zhang H, Cheng Y. 2016. Multi-sensor monitoring of Ulva prolifera blooms in the Yellow Sea using different methods. Frontiers of Earth Science 10:378-388 DOI 10.1007/s11707-015-0528-1.

Xu Z, Gao G, Xu J, Wu H. 2017. Physiological response of a golden tide alga (Sargassum muticum) to the interaction of ocean acidification and phosphorus enrichment. Biogeosciences 4:671-681 DOI 10.5194/bg-14-671-2017.

Young CS, Gobler CJ. 2016. Ocean acidification accelerates the growth of two bloom-forming macroalgae. PloS one 11:e 0155152

DOI 10.1371/journal.pone. 0155152 .

Zhang D, Zhang Q, Yang X. 2017. Seasonal dynamics of photosynthetic activity in the representive brown macroalgae Sagrassum thunbergii (Sargassaceae Phaeophyta). Plant Physiol Biochem 120:88-94

DOI 10.1016/j.plaphy.2017.09.025.

Zou D. 2005. Effects of elevated atmospheric $\mathrm{CO}_{2}$ on growth, photosynthesis and nitrogen metabolism in the economic brown seaweed, Hizikia fusiforme (Sargassaceae, Phaeophyta). Aquaculture 250:726-735 
DOI 10.1016/j.aquaculture.2005.05.014.

488 Zou D, Gao K, Ruan Z. 2007. Daily timing of emersion and elevated atmospheric $\mathrm{CO}_{2}$ concentration affect photosynthetic performance of the intertidal macroalga Ulva lactuca (Chlorophyta) in sunlight. Botanica Marina 50:275-279 DOI 10.1515/BOT.2007.031.

491 Zucchi MR, Necchi O. 2001. Effects of temperature, irradiance and photoperiod on growth and 492 pigment content in some freshwater red algae in culture. Phycological Research 49:103-114 493 DOI 10.1046/j.1440-1835.2001.00230.x. 


\section{Figure legend}

495

496

497

Fig. 1. Relative growth rate (RGR) of $U$. linza thalli grown at different $\mathrm{CO}_{2}$ levels (400 ppm, LC; $1000 \mathrm{ppm}, \mathrm{HC})$ and different photoperiods (L: $\mathrm{D}=8: 16,12: 12,16: 8)$. Vertical bars are mean \pm SD for triplicate samples. Different lowercase letters denote significant difference among the photoperiod levels at LC and different capital letters denote significant difference among the photoperiod levels at $\mathrm{HC}$. Significant differences between two $\mathrm{CO}_{2}$ levels under the same photoperiod are indicated by short lines.

Fig. 2. Yield (A) and NPQ (B) of $U$. linza thalli grown at different $\mathrm{CO}_{2}$ levels (400 ppm, LC; $1000 \mathrm{ppm}, \mathrm{HC})$ and different photoperiods $(\mathrm{L}: \mathrm{D}=8: 16,12: 12,16: 8)$. Vertical bars are mean \pm SD for triplicate samples. Different lowercase letters denote significant difference among the photoperiod levels at LC and different capital letters denote significant difference among the photoperiod levels at HC. Significant differences between two $\mathrm{CO}_{2}$ levels under the same photoperiod are indicated by short lines.

Fig. 3. Rapid light curves (RLC) of $U$. linza thalli grown at ambient $\mathrm{CO}_{2}$ levels $(400 \mathrm{ppm}, \mathrm{LC}, \mathrm{A}$; 1000 ppm, HC, B) and different photoperiods (L: $\mathrm{D}=8: 16,12: 12,16: 8$ ).

Fig. 4. Respiration rate of $U$. linza thalli grown at different $\mathrm{CO}_{2}$ levels $(1000 \mathrm{ppm}, \mathrm{HC})$ and different photoperiods ( $\mathrm{L}: \mathrm{D}=8: 16,12: 12,16: 8)$. Vertical bars are mean \pm SD for triplicate samples. Different lowercase letters denote significant difference among the photoperiod levels at LC and different capital letters denote significant difference among the photoperiod levels at HC. Significant differences between two $\mathrm{CO}_{2}$ levels under the same photoperiod are indicated by short lines.

Fig. 5. Content of the pigments $\mathrm{Chl} a(\mathrm{~A})$ and $\mathrm{Chl} b(\mathrm{~B})$, and the $\mathrm{Chl} a / b$ ratio (C) of $U$. linza thalli grown at different $\mathrm{CO}_{2}$ levels (400 ppm, LC; 1000 ppm, HC) and different photoperiods (L: $\mathrm{D}=8: 16,12: 12,16: 8)$. Vertical bars are mean $\pm \mathrm{SD}$ for triplicate samples. Different lowercase letters denote significant difference among the photoperiod levels at LC and different capital letters denote significant difference among the photoperiod levels at HC. Significant differences between two $\mathrm{CO}_{2}$ levels under the same photoperiod are indicated by short lines. 
Figure 1

Relative growth rate.

Relative growth rate (RGR) of $U$. linza thalli grown at different $\mathrm{CO}_{2}$ levels (400 ppm, LC; 1000 ppm, HC) and different photoperiods (L: $D=8: 16,12: 12,16: 8$ ).

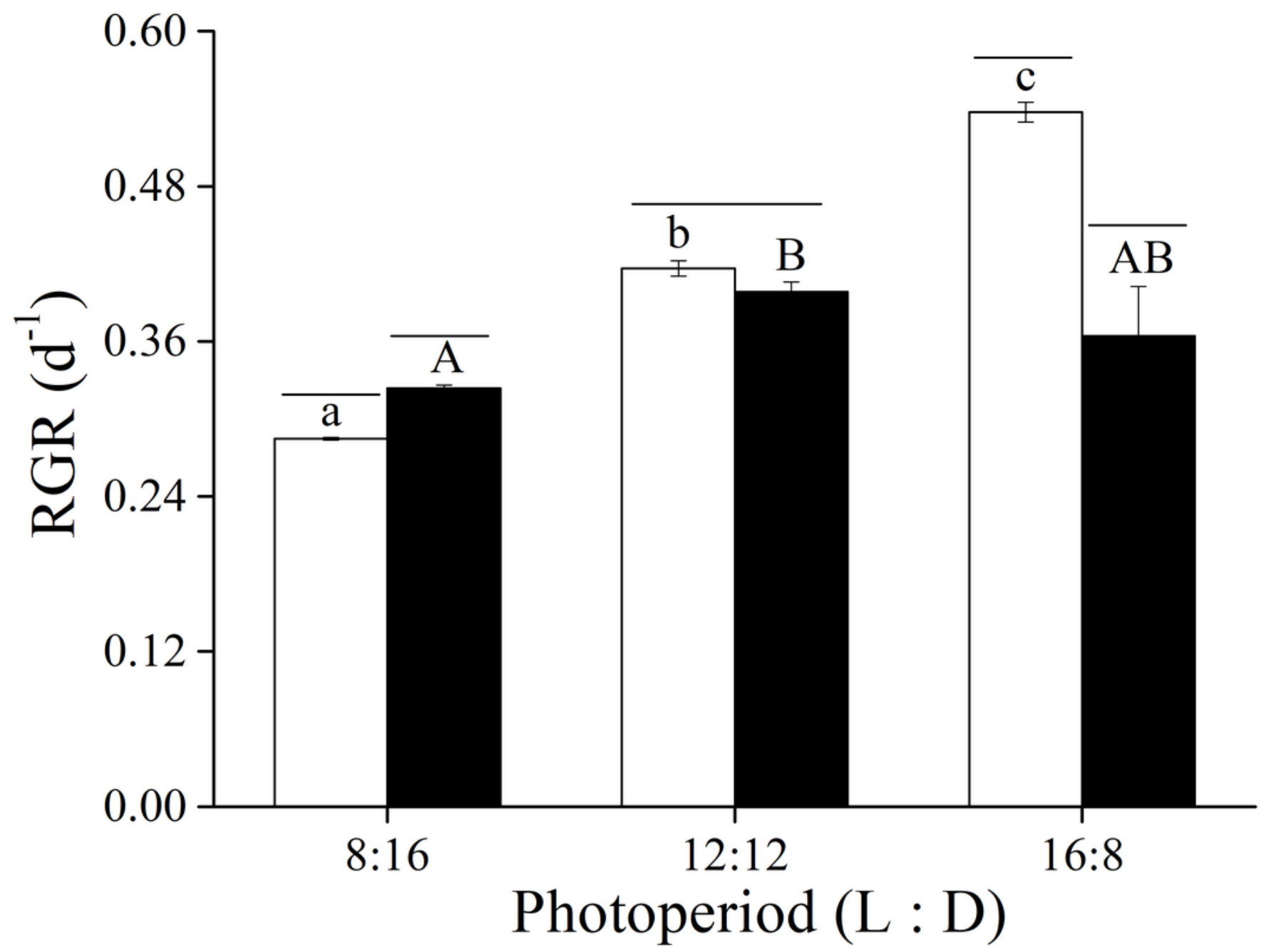


Figure 2

Yield and NPQ.

Yield (A) and NPQ (B) of $U$. linza thalli grown at different $\mathrm{CO}_{2}$ levels (400 ppm, LC; 1000 ppm, HC) and different photoperiods (L: $D=8: 16,12: 12,16: 8$ ). 

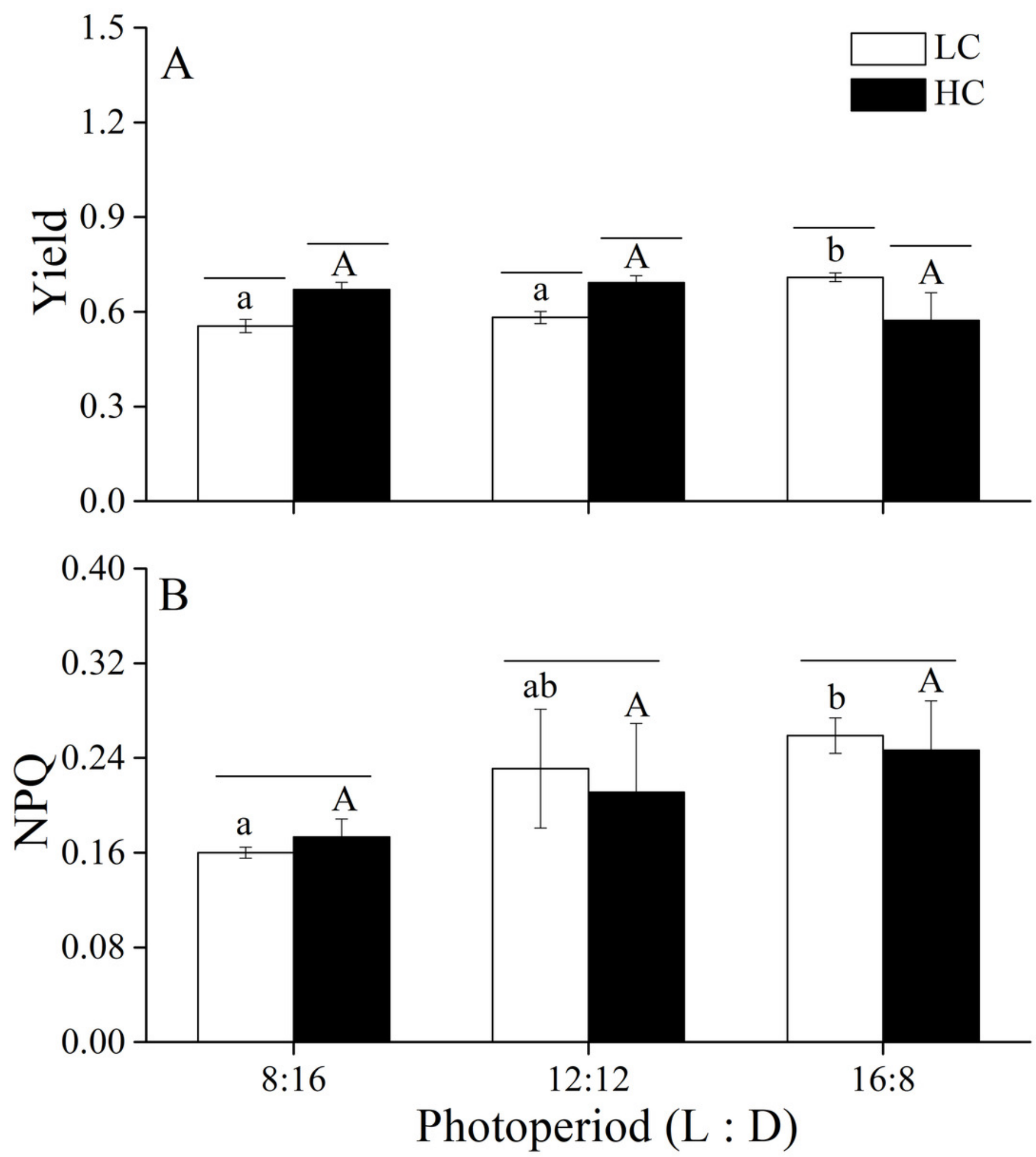
Figure 3

Rapid light curves.

Rapid light curves (RLC) of $U$. linza thalli grown at different $\mathrm{CO}_{2}$ levels (400 ppm, $\mathrm{LC} ; 1000 \mathrm{ppm}, \mathrm{HC}$ ) and different photoperiods (L: $D=8: 16,12: 12,16: 8$ ). 


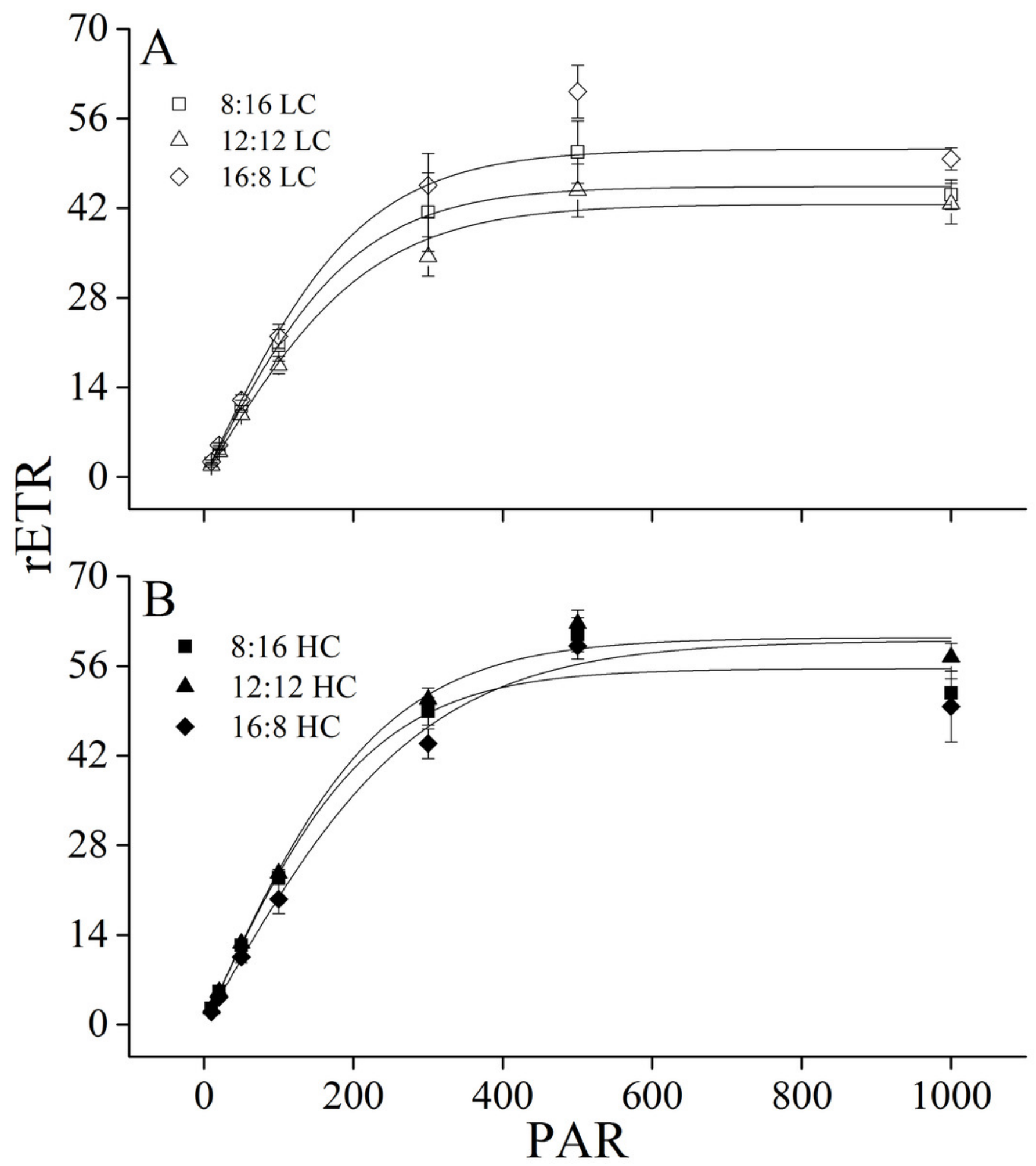


Figure 4

Respiration rate.

Respiration rate of $U$. linza thalli grown at different $\mathrm{CO}_{2}$ levels (400 ppm, LC; 1000 ppm, HC) and different photoperiods ( $L: D=8: 16,12: 12,16: 8$ ).

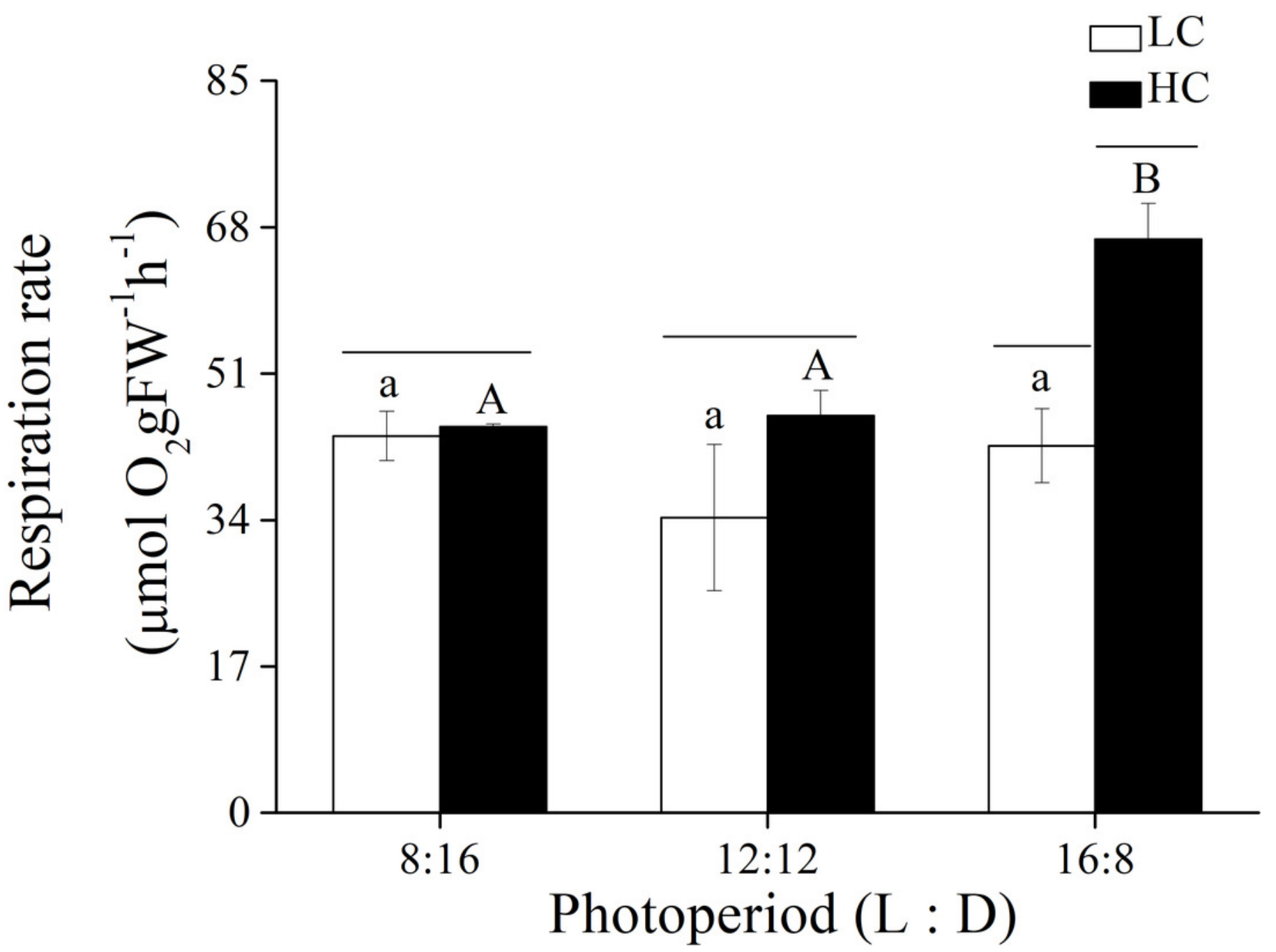


Figure 5

Pigment contents and the $\mathrm{Chl} a / b$ ratio.

Pigment contents ( $\mathrm{Chl} a, \mathrm{~A} ; \mathrm{Chl} b, \mathrm{~B}$ ) and the $\mathrm{Chl} a / b$ ratio (C) of $U$. linza thalli grown at different $\mathrm{CO}_{2}$ levels $(400 \mathrm{ppm}, \mathrm{LC} ; 1000 \mathrm{ppm}, \mathrm{HC}$ ) and different photoperiods $(\mathrm{L}: \mathrm{D}=8: 16$, $12: 12,16: 8)$. 

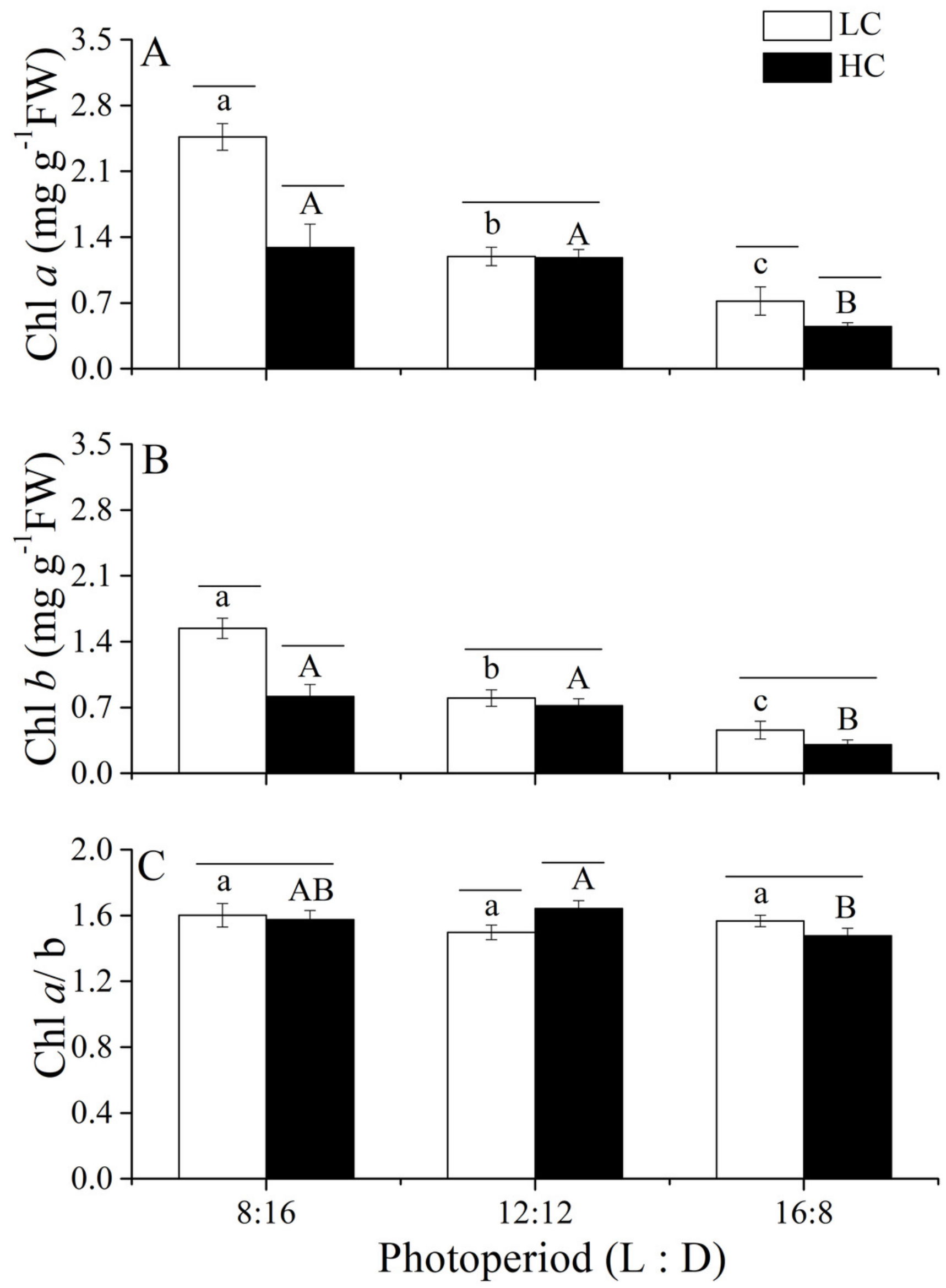

Peer) reviewing PDF | (2019:02:35151:2:0:ACCEPTED 12 Apr 2019) 


\section{Table $\mathbf{1}$ (on next page)}

Parameters of the seawater carbonate system in different cultures. DIC $=$ dissolved inorganic carbon, $T A=$ total alkalinity. Data are the mean $\pm S D(n=3)$.

TA $=$ total alkalinity. Data are the mean \pm SD $(n=3)$. 
1 Table 1. Parameters of the seawater carbonate system in different cultures. DIC $=$ dissolved inorganic carbon, TA $=$ total alkalinity. 2 Data are the mean $\pm \mathrm{SD}(\mathrm{n}=3)$.

\begin{tabular}{|c|c|c|c|c|c|c|c|}
\hline & $\mathrm{pH}_{\mathrm{NBS}}$ & $p \mathrm{CO}_{2}(\mu \mathrm{atm})$ & $\mathrm{DIC}\left(\mu \mathrm{mol} \mathrm{kg}{ }^{-1}\right)$ & $\mathrm{HCO}_{3}^{-}\left(\mu \mathrm{mol} \mathrm{kg}{ }^{-1}\right)$ & $\mathrm{CO}_{3}^{2-}\left(\mu \mathrm{mol} \mathrm{kg}{ }^{-1}\right)$ & $\mathrm{CO}_{2}\left(\mu \mathrm{mol} \mathrm{kg}{ }^{-1}\right)$ & $\mathrm{TA}\left(\mu \mathrm{mol} \mathrm{kg}{ }^{-1}\right)$ \\
\hline $8: 16 \mathrm{LC}$ & $8.14 \pm 0.02^{\mathrm{a}}$ & $580.32 \pm 35.74^{\mathrm{a}}$ & $2597.04 \pm 57^{\mathrm{a}}$ & $2385.19 \pm 56.15^{\mathrm{a}}$ & $192.59 \pm 7.23^{\mathrm{a}}$ & $19.56 \pm 1.19^{a}$ & $2850.78 \pm 56.26^{\mathrm{a}}$ \\
\hline 12:12 LC & $8.12 \pm 0.01^{\mathrm{a}}$ & $613.13 \pm 11.21^{\mathrm{a}}$ & $2594.32 \pm 61.96^{\mathrm{a}}$ & $2391.03 \pm 55.85^{\mathrm{a}}$ & $182.94 \pm 6.07^{\mathrm{a}}$ & $20.35 \pm 0.37^{\mathrm{a}}$ & $2834.31 \pm 67.99^{a}$ \\
\hline $16: 8 \mathrm{LC}$ & $8.13 \pm 0.01^{\mathrm{a}}$ & $608.54 \pm 14.83^{a}$ & $2638.26 \pm 40.24^{\mathrm{a}}$ & $2427.94 \pm 35.09^{a}$ & $190.12 \pm 6.73^{\mathrm{a}}$ & $20.19 \pm 0.49^{a}$ & $2886.86 \pm 46.67^{\mathrm{a}}$ \\
\hline $8: 16 \mathrm{HC}$ & $7.74 \pm 0.03^{b}$ & $1614.77 \pm 100.05^{b}$ & $2780.28 \pm 12.05^{b}$ & $2641.71 \pm 12.23^{b}$ & $84.99 \pm 5.08^{b}$ & $53.58 \pm 3.32^{b}$ & $2854.16 \pm 13.32^{\mathrm{a}}$ \\
\hline $12: 12 \mathrm{HC}$ & $7.79 \pm 0.02^{\mathrm{cd}}$ & $1445.67 \pm 58.75^{c}$ & $2799.47 \pm 14.61^{b}$ & $2655.70 \pm 13.74^{b}$ & $95.80 \pm 3.81^{b}$ & $47.97 \pm 1.95^{\mathrm{c}}$ & $2893.15 \pm 17.18^{\mathrm{a}}$ \\
\hline $16: 8 \mathrm{HC}$ & $7.75 \pm 0.01^{\mathrm{bd}}$ & $1652.45 \pm 43.38^{\mathrm{b}}$ & $2938.18 \pm 47.63^{c}$ & $2790.86 \pm 45.52^{\mathrm{c}}$ & $92.48 \pm 1.28^{b}$ & $54.83 \pm 1.44^{\mathrm{b}}$ & $3019.14 \pm 46.95^{\mathrm{b}}$ \\
\hline
\end{tabular}

3 


\section{Table 2 (on next page)}

Two-way ANOVA analysis of variance for the effects of $\mathrm{CO}_{2}$ and photoperiod on $\mathrm{pH}$, $p \mathrm{CO}_{2}$, dissolved inorganic carbon (DIC), $\mathrm{HCO}_{3}{ }^{-}, \mathrm{CO}_{3}{ }^{2-}, \mathrm{CO}_{2}$ and total alkalinity (TA) in seawater.

$\mathrm{CO}_{2}{ }^{*}$ photoperiod means the interactive effects of $\mathrm{CO}_{2}$ and photoperiod, $\mathrm{df}$ mean degree of freedom and $F$ means the value of $F$ statistic, and Sig. means $p$-value. 
1 Table 2. Two-way ANOVA analysis of variance for the effects of $\mathrm{CO}_{2}$ and photoperiod regimes on $\mathrm{pH}, p \mathrm{CO}_{2}$, dissolved inorganic 2 carbon (DIC), $\mathrm{HCO}_{3}{ }^{-}, \mathrm{CO}_{3}{ }^{2-}, \mathrm{CO}_{2}$ and total alkalinity (TA) in seawater. $\mathrm{CO}_{2}{ }^{*}$ photoperiod means the interactive effects of $\mathrm{CO}_{2}$ and 3 photoperiod, df mean degree of freedom and $\mathrm{F}$ means the value of $\mathrm{F}$ statistic, and Sig. means $p$-value.

\begin{tabular}{|c|c|c|c|c|c|c|c|c|c|c|c|c|c|c|c|}
\hline \multirow[t]{2}{*}{ Source } & \multicolumn{3}{|c|}{$\mathrm{pH}$} & \multicolumn{2}{|l|}{$p \mathrm{CO}_{2}$} & \multicolumn{2}{|l|}{ DIC } & \multicolumn{2}{|l|}{$\mathrm{HCO}_{3}^{-}$} & \multicolumn{2}{|l|}{$\mathrm{CO}_{3}^{2-}$} & \multicolumn{2}{|l|}{$\mathrm{CO}_{2}$} & \multicolumn{2}{|l|}{$\mathrm{TA}$} \\
\hline & $\mathrm{df}$ & $\mathrm{F}$ & Sig. & F & Sig. & $\mathrm{F}$ & Sig. & $\mathrm{F}$ & Sig. & $\mathrm{F}$ & Sig. & $\mathrm{F}$ & Sig. & $\mathrm{F}$ & Sig. \\
\hline Photoperiod & 2 & 1.333 & 0.3 & 5.640 & 0.019 & 9.697 & 0.003 & 10.112 & 0.003 & .353 & 0.710 & 5.632 & 0.019 & 8.638 & 0.005 \\
\hline $\mathrm{CO}_{2}$ & 1 & 2268.750 & $<0.001$ & 1498.294 & $<0.001$ & 125.390 & $<0.001$ & 236.530 & $<0.001$ & 1453.669 & $<0.001$ & 1497.372 & $<0.001$ & 8.977 & 0.011 \\
\hline Photoperiod $* \mathrm{CO}_{2}$ & 2 & 7.750 & 0.007 & 7.562 & 0.007 & 3.054 & 0.085 & 3.184 & 0.078 & 5.342 & 0.022 & 7.557 & 0.008 & 2.976 & 0.089 \\
\hline Error & 12 & & & & & & & & & & & & & & \\
\hline
\end{tabular}

4 


\section{Table 3(on next page)}

Two-way ANOVA analysis of variance for the effects of $\mathrm{CO}_{2}$ and photoperiod regimes on RGR of Ulva linza cultured at different $\mathrm{CO}_{2}$ levels and photoperiod regimes.

$\mathrm{CO}_{2}$ *photoperiod means the interactive effects of $\mathrm{CO}_{2}$ and photoperiod, df mean degree of freedom and $\mathrm{F}$ means the value of $\mathrm{F}$ statistic, and Sig. means $p$-value. 
1 Table 3. Two-way ANOVA analysis of variance for the effects of $\mathrm{CO}_{2}$ and photoperiod regimes

2 on RGR of Ulva linza cultured at different $\mathrm{CO}_{2}$ levels and photoperiod regimes.

$3 \mathrm{CO}_{2}$ * photoperiod means the interactive effects of $\mathrm{CO}_{2}$ and photoperiod, $\mathrm{df}$ mean degree of

4 freedom and F means the value of F statistic, and Sig. means $p$-value.

\begin{tabular}{cccc}
\hline Source & df & F & Sig. \\
\hline Photoperiod & 2 & 124.249 & $<0.001$ \\
$\mathrm{CO}_{2}$ & 1 & 42.292 & $<0.001$ \\
Photoperiod* $\mathrm{CO}_{2}$ & 2 & 65.959 & $<0.001$ \\
Error & 12 & & \\
\hline
\end{tabular}

5 


\section{Table 4 (on next page)}

Two-way ANOVA analysis of variance for the effects of $\mathrm{CO}_{2}$ and photoperiod regimes on Yield and NPQ of Ulva linza cultured at different $\mathrm{CO}_{2}$ levels and photoperiod regimes.

$\mathrm{CO}_{2}{ }^{*}$ photoperiod means the interactive effects of $\mathrm{CO}_{2}$ and photoperiod, df mean degree of freedom and $\mathrm{F}$ means the value of $\mathrm{F}$ statistic, and Sig. means $p$-value. 
1 Table 4. Two-way ANOVA analysis of variance for the effects of $\mathrm{CO}_{2}$ and photoperiod regimes

2 on Yield and NPQ of Ulva linza cultured at different $\mathrm{CO}_{2}$ levels and photoperiod regimes.

$3 \mathrm{CO}_{2}$ * photoperiod means the interactive effects of $\mathrm{CO}_{2}$ and photoperiod, $\mathrm{df}$ mean degree of

4 freedom and F means the value of F statistic, and Sig. means $p$-value.

\begin{tabular}{|c|c|c|c|c|c|c|}
\hline \multirow[t]{2}{*}{ Source } & \multicolumn{3}{|c|}{ Yield } & \multicolumn{3}{|c|}{ NPQ } \\
\hline & $\mathrm{df}$ & $\mathrm{F}$ & Sig. & $\mathrm{df}$ & $\mathrm{F}$ & Sig. \\
\hline Photoperiod & 2 & 0.919 & 0.425 & 2 & 8.453 & 0.005 \\
\hline $\mathrm{CO}_{2}$ & 1 & 2.549 & 0.136 & 1 & 0.132 & 0.722 \\
\hline Photoperiod* $\mathrm{CO}_{2}$ & 2 & 19.786 & $<0.001$ & 2 & 0.339 & 0.719 \\
\hline Error & 12 & & & 12 & & \\
\hline
\end{tabular}

5 


\section{Table 5 (on next page)}

Parameters of rapid light curves (RLC) of $U$. linza thalli cultured at different $\mathrm{CO}_{2}$ levels and photoperiod regimes.

Data are the mean $\pm S D(n \geqq 3)$. Different letters represent significant difference $(p<0.05)$ among different treatments. 
1 Table 5. Parameters of rapid light curves (RLC) of $U$. linza thalli cultured at different $\mathrm{CO}_{2}$ levels

2 and photoperiod regimes. Data are the mean $\pm \mathrm{SD}(\mathrm{n} \geqq 3)$. Different letters represent significant

3 difference $(p<0.05)$ among different treatments.

\begin{tabular}{cccc}
\hline & rETRmax & $\alpha$ & $\mathrm{I}_{\mathrm{k}}$ \\
\hline $8: 16 \mathrm{LC}$ & $47.53 \pm 3.63^{\mathrm{a}}$ & $0.22 \pm 0.04^{\mathrm{a}}$ & $215.67 \pm 19.89^{\mathrm{a}}$ \\
$12: 12 \mathrm{LC}$ & $43.87 \pm 3.60^{\mathrm{c}}$ & $0.18 \pm 0.02^{\mathrm{c}}$ & $248.87 \pm 22.91^{\mathrm{bd}}$ \\
$16: 8 \mathrm{LC}$ & $54.83 \pm 2.65^{\mathrm{b}}$ & $0.24 \pm 0.03^{\mathrm{ab}}$ & $231.58 \pm 21.37^{\text {adef }}$ \\
$8: 16 \mathrm{HC}$ & $56.51 \pm 2.34^{\mathrm{b}}$ & $0.25 \pm 0.01^{\mathrm{b}}$ & $222.15 \pm 13.41^{\mathrm{ac}}$ \\
$12: 12 \mathrm{HC}$ & $60.45 \pm 1.38^{\mathrm{d}}$ & $0.26 \pm 0.01^{\mathrm{b}}$ & $236.58 \pm 12.63^{\mathrm{bce}}$ \\
$16: 8 \mathrm{HC}$ & $54.55 \pm 3.77^{\mathrm{b}}$ & $0.22 \pm 0.01^{\mathrm{a}}$ & $251.72 \pm 11.69^{\mathrm{bf}}$ \\
\hline
\end{tabular}

4 


\section{Table 6 (on next page)}

Two-way ANOVA analysis of variance for the effects of $\mathrm{CO}_{2}$ and photoperiod regimes on maximum rETR ( $r E T R m a x)$, efficiency of electron transport $(\alpha)$, and saturating irradiance $\left(I_{k}\right)$ of Ulva linza.

$\mathrm{CO}_{2}{ }^{*}$ photoperiod means the interactive effects of $\mathrm{CO}_{2}$ and photoperiod, $\mathrm{df}$ mean degree of freedom and $\mathrm{F}$ means the value of $\mathrm{F}$ statistic, and Sig. means $p$-value. 
1 Table 6. Two-way ANOVA analysis of variance for the effects of $\mathrm{CO}_{2}$ and photoperiod regimes on maximum $\mathrm{rETR}$ ( $\mathrm{rETRmax}$ ),

2 efficiency of electron transport $(\alpha)$, and saturating irradiance $\left(\mathrm{I}_{\mathrm{k}}\right)$ of Ulva linza cultured at different $\mathrm{CO}_{2}$ levels and photoperiod

3 regimes. $\mathrm{CO}_{2}$ * photoperiod means the interactive effects of $\mathrm{CO}_{2}$ and photoperiod, df mean degree of freedom and $\mathrm{F}$ means the value of

$4 \quad$ F statistic, and Sig. means $p$-value.

\begin{tabular}{|c|c|c|c|c|c|c|c|c|c|}
\hline \multirow[t]{2}{*}{ Source } & \multicolumn{3}{|c|}{ ETRmax } & \multicolumn{3}{|c|}{$\alpha$} & \multicolumn{3}{|c|}{$\mathrm{I}_{\mathrm{k}}$} \\
\hline & Df & $\mathrm{F}$ & Sig. & $\mathrm{df}$ & $\mathrm{F}$ & Sig. & $\mathrm{df}$ & $\mathrm{F}$ & Sig. \\
\hline Photoperiod & 2 & 2.981 & 0.066 & 2 & 2.909 & 0.070 & 2 & 7.030 & 0.003 \\
\hline $\mathrm{CO}_{2}$ & 1 & 69.993 & $<0.001$ & 1 & 15.225 & $<0.001$ & 1 & 0.664 & 0.421 \\
\hline Photoperiod* $\mathrm{CO}_{2}$ & 2 & 23.445 & $<0.001$ & 2 & 14.896 & $<0.001$ & 2 & 2.576 & 0.093 \\
\hline Error & 30 & & & 30 & & & 30 & & \\
\hline
\end{tabular}

5 


\section{Table 7(on next page)}

Two-way ANOVA analysis of variance for the effects of $\mathrm{CO}_{2}$ and photoperiod regimes on respiration rate of Ulva linza cultured at different $\mathrm{CO}_{2}$ levels and photoperiod regimes.

$\mathrm{CO}_{2}{ }^{*}$ photoperiod means the interactive effects of $\mathrm{CO}_{2}$ and photoperiod, df mean degree of freedom and $\mathrm{F}$ means the value of $F$ statistic, and Sig. means $p$-value. 
1 Table 7. Two-way ANOVA analysis of variance for the effects of $\mathrm{CO}_{2}$ and photoperiod regimes

2 on respiration rate of Ulva linza cultured at different $\mathrm{CO}_{2}$ levels and photoperiod regimes.

$3 \mathrm{CO}_{2}$ * photoperiod means the interactive effects of $\mathrm{CO}_{2}$ and photoperiod, $\mathrm{df}$ mean degree of

4 freedom and F means the value of F statistic, and Sig. means $p$-value.

\begin{tabular}{cccc}
\hline Source & df & F & Sig. \\
\hline Photoperiod & 2 & 16.006 & $<0.001$ \\
$\mathrm{CO}_{2}$ & 1 & 33.058 & $<0.001$ \\
Photoperiod* $\mathrm{CO}_{2}$ & 2 & 9.566 & 0.003 \\
Error & 12 & & \\
\hline
\end{tabular}

5 


\section{Table 8 (on next page)}

Two-way ANOVA analysis of variance for the effects of $\mathrm{CO}_{2}$ and photoperiod regimes on

$\mathrm{Chl} a$, Chl $b$, and $\mathrm{Chl} a$ / $b$ of Ulva linza cultured at different $\mathrm{CO}_{2}$ levels and photoperiod regimes.

$\mathrm{CO}_{2}{ }^{*}$ photoperiod means the interactive effects of $\mathrm{CO}_{2}$ and photoperiod, df mean degree of freedom and $\mathrm{F}$ means the value of $\mathrm{F}$ statistic, and Sig. means $p$-value. 
1 Table 8. Two-way ANOVA analysis of variance for the effects of $\mathrm{CO}_{2}$ and photoperiod regimes on $\mathrm{Chl} a$, Chl $b$, and $\mathrm{Chl} a / b$ of $U l v a$

2 linza cultured at different $\mathrm{CO}_{2}$ levels and photoperiod regimes. $\mathrm{CO}_{2}$ *photoperiod means the interactive effects of $\mathrm{CO}_{2}$ and photoperiod,

3 df mean degree of freedom and F means the value of F statistic, and Sig. means $p$-value.

\begin{tabular}{|c|c|c|c|c|c|c|c|c|c|}
\hline \multirow[t]{2}{*}{ Source } & \multicolumn{3}{|c|}{ Chl $a$} & \multicolumn{3}{|c|}{ Chl $b$} & \multicolumn{3}{|c|}{ Chl $a / b$} \\
\hline & $\mathrm{df}$ & $\mathrm{F}$ & Sig. & $\mathrm{df}$ & $\mathrm{F}$ & Sig. & $\mathrm{df}$ & $\mathrm{F}$ & Sig. \\
\hline Photoperiod & 2 & 121.283 & $<0.001$ & 2 & 111.035 & $<0.001$ & 2 & 2.625 & 0.113 \\
\hline $\mathrm{CO}_{2}$ & 1 & 51.793 & $<0.001$ & 1 & 53.849 & $<0.001$ & 1 & 0.171 & 0.686 \\
\hline Photoperiod $* \mathrm{CO}_{2}$ & 2 & 26.932 & $<0.001$ & 2 & 21.719 & $<0.001$ & 2 & 8.389 & 0.005 \\
\hline Error & 12 & & & 12 & & & 12 & & \\
\hline
\end{tabular}

4 